\title{
Management of Contracting Public Services and its Quality in Slovakia
}

\author{
Juraj Nemec ${ }^{1}$, Beáta Mikušová Meričkováa, Zuzana Vozárová ${ }^{3}$
}

\section{Abstract}

Contracting services in the public sector with private for-profit and non-profit firms is one of the most prevalent types of alternative service-delivering arrangements. Concerning the positive potential of contracting, the relevant literature proposes that contracting may, but need not, improve individual choice, cost-effectiveness and the quality of delivery, equity and to some extent also expenditure control. On the other hand, many authors provide important arguments describing weak points of contracting and some risks connected with contracting services in the public sector. The main "internal" reason why contracting does not produce the expected results and even creates perverse effects in the effectiveness and quality of contracted services, is the improper implementation of contract management. This paper seeks to answer the question of what factors account for success in contracting for services in the public sector by testing the relationship between contracting performance and selected factors connected with contract management such as competition, exante evaluation of bidders, contract monitoring, contract duration, contract payment and joint problem solving and communication between the principal and the agent. This study uses a quantitative approach to investigate the research question and to analyze the original collected survey data from our own research.

The research was supported by the Czech Grant Agency projects P403/12/0366 and $\mathrm{P} 403 / 10 / 1892$

1 Professor, Masaryk University Brno, Czech Republic and Faculty of Economics, Matej Bel University, Banska Bystrica, Slovakia, E-mail: juraj.nemec@umb.sk

2 Associate Professor, Faculty of Economics, Matej Bel University, Banska Bystrica, Slovakia and Banking Institute, Prague, Czech Republic, E-mail: beata.merickova@umb.sk

3 PhD student, Faculty of Economics, Matej Bel University, Banska Bystrica, Slovakia and Banking Institute, Prague, Czech Republic, E-mail: zuzana.vozarova@umb.sk 
Key words: Contracting, outsourcing, public sector, principal, agent, contract management.

\section{Introduction}

Our data (Meričková, Nemec and Vítek 2005, Meričková, Nemec and Ochrana 2008, Meričková, Nemec, Sičáková-Beblavá and Beblavý 2010) and data of other authors for the Czech Republic and Slovakia (Balážová 2006; Beblavý and SičákováBeblavá 2006; Majlingová and Šagát 2006, Sičáková-Beblavá and Beblavý 2007, Ochrana 2007; Pavel 2007) evaluating outcomes from contracting (we use this term as a synonym for external delivery of public services - like waste disposal) and outsourcing (we use this term as a synonym for external delivery of internal services in public organizations - like cleaning) processes in the public sector indicate that the use of these instruments in our conditions does not deliver the expected results. Contracting and outsourcing are controversial instruments already because of their character, and their cons might be exaggerated in less developed countries - this aspect is demonstrated in the first part of our paper. At the end of this first part, we will provide selected evidence about results of contracting and outsourcing in our conditions.

Results from contracting and outsourcing (as a binding agreement in which a government (principal/provider) pays a private firm or non-profit organization (agent/producer) to deliver a specific level and quality of service) are determined by many "internal" and "external" factors determining their success. The focus of the core part of our paper is the evaluation of contract-management factors determining the rate of success of contracting and outsourcing on the basis of the Slovak sample.

The research was supported by the Czech Grant Agency (GACR), projects $\mathrm{P} 403 / 10 / 1892$ and $\mathrm{P} 403 / 12 / 0366$.

\section{Theoretical background}

Contracting out public services is a frequently implemented market-type solution in the public sector, implemented especially at the local government level. Under this arrangement, government retains the responsibility for the provision of the service, but hires private firms to produce the service. Citizens as customers, through their taxes or user fees, pay the government, which in turn pays the contractor.

Contracting stems from the "organizational decision to make or buy a good or service" (Prager 1994, 176). Modern public organizations are expected to decide whether to produce goods and services internally or to contract them out. The guiding principle behind the choice is to increase efficiency, while maintaining or 
increasing the quality of the delivery of a public service (Engelbeck 2004; Epstein 1984).

As noted above, contracting has the potential to improve efficiency without sacrificing quality, compared with direct supply by public organizations, so long as certain conditions are met. The potential beneficial impacts of contracting are connected mainly with increasing individual choice and improved cost-effectiveness, quality and equity (Bailey 1999; Øvretveit 1995; Lane 2000 and many others). However, such potential was never fully confirmed by hard data, and many empirical studies (e.g. Bel and Costas 2006) cannot even confirm the effect of the mode of production on costs, which has been the main positive argument for contracting. Moreover some authors stress the many barriers and also negative impacts connected with the use of competition and contracting (Bailey 1999; Pollitt and Bouckaert 2000; Lane 2000 and many others). For example Lowery (1998) discusses three types of quasi-market failure, two of them, market-formation failure and preference error, are clearly connected with contracting out. Market-formation failure results from a lack of competition, often due to the small number of potential suppliers for many public services. If privatization merely substitutes a private monopoly for a public one, then savings will likely disappear after the initial contract. Preferenceerror failure is connected with limited information. Later on in the text, we specifically introduce two core theoretical concepts important for evaluating the potential of contracting out: principal-agent theory (Arrow 1985; Cooper 2003; Kettl 1993; More 1984; Pratt and Zeckhauser 1986) and the theory of transaction costs (Ferris and Graddy 1996; Prager 1994; Hirsch 1991).

The issue of factors determining the success of contracting/outsourcing is not new in the economic literature. The main focus of existing studies is on the following aspects:

- the degree of competition for awarding the contract (Savas 1987; Kettl 1993; Greene 2002; Hodge 2000, Pavel and Beblavá 2008),

- the quality of ex-ante evaluation of the contractor/agent (Rehfuss 1989; Marlin 1984; Romzek and Johnston 2002),

- the clear definition of the contracted/outsourced service - contract specification (Rehfuss 1989, Marlin 1984),

- the quality of contract monitoring (Rehfuss 1989; Marlin 1984; Prager 1994; Seidenstat 1999; Brown and Potoski 2003; Hefetz and Warner 2004),

- sanctions (DeHoog 1990; Macneil 1978),

- the experience of the public body/government/principal responsible for contracting/outsourcing with contract management (DeHoog 1990; Rehfuss 1989; Romzek and Johnston 2002),

- the technical knowledge of the contracted service (Kettl 1993; Meričková 2010). 


\section{Principal-agent theory and contracting}

Establishing and maintaining a legal contractual relationship between principal and agent is connected with many problems and risks. According to Shetterly (1998, 23), this process occurs in three phases; pre-solicitation, contractor selection and contract management. All these phases may be connected with the situation when the action and the information of agents are not directly observable by principals. Arrow $(1985,37)$, for example, speaks of "moral hazard or the problem of hidden action and adverse selection or the problem of hidden information."

Moral hazard can occur because the behavior of the private partner is imperfectly controlled. When behavior is imperfectly controlled, it creates a situation where either shirking in performance of duties or inappropriate actions by the private partner adversely impacts the goals of the public partner.

In the adverse-selection problem, the private firm has some information that is not shared with the public-sector organization and uses the information to make decisions that affect the public organization. However, the public organization cannot check to see if the information is serving the public interest. For example, the public-sector organization wants to hire the best private partner. But the private firm will know more about their own qualifications than will the public-sector organization. This information asymmetry may render impossible a full ex-ante evaluation of the private offers. Bailey $(1999,290-292)$ examines the effects of such publicservice-contracting problems.

According to More, "The principal must weave these interrelated components into a contractual framework that, in mitigating the informational asymmetries and structuring rewards, prompts the agent to behave as the principal himself would under whatever conditions might prevail" (More 1984, 756-757).

\section{Transactions costs and contracting}

The transaction costs associated with contracting out and the relationship of these costs to benefits derived from external delivery should be included in the complexity of the contracting relationship. When contracting for services, governments incur contracting costs which are implicitly or explicitly part of the make-or-buy decision. The transaction costs of contracting are of two types: "those associated with the contract formation stage and those associated with the contract performance stage" (Hirsch 1991, 56-57).

Changing service delivery involves changes to production systems and changes to management systems. These changes require establishing new performance criteria, constructing monitoring systems and changing job responsibilities, reducing the number of public employees. Activities such as crafting requests for proposals, establishing systems and protocols for reviewing proposals and selecting vendors, crafting contracts, and negotiating with vendors must be undertaken be- 
fore the internal delivery system can be taken off-line. These transaction costs of switching modes of service delivery or costs of acquiring the services in the market are important to the make-or-buy decision. Different services have different levels of transaction-cost factors, in part determined by asset specificity and ease of measurement explained by the transaction-cost theory noted above.

\subsection{Contracting out in transitional countries}

The theory summarized above indicates that in developed countries, contracting may, but need not, improve the performance of the public sector. The final outcome depends on local conditions, including the capacity of the implementing body to execute the contracting process.

In transitional countries, the situation is much more complicated. Several socio-economic preconditions for successful contracting are insufficiently developed. In such a situation - due to non-mature markets and democratic institutions, in developing countries internalization may be a desirable decision. In the following text we indicate selected important specifics of developing versus developed countries.

\section{Competition}

Potentially competitive markets may still not be well developed, but characterized by monopolistic or oligopolistic structures and behavior. Given this, it is rather optimistic to expect a comprehensive supply of competitive bids. Under these circumstances, the argument about possible unit cost savings is far more controversial than in developed countries.

\section{Corruption}

It is difficult to measure corruption, but all data indicate higher risks of corruption in developing transition countries compared to developed countries. The probably most frequently used Transparency International CPI indexes describe perceptions of corruption, not direct measurements (Table 1). This methodology is sensitive to the level of awareness - when respondents become more aware of the problem, results worsen.

Data from "Enterprise Surveys" are also significant. Table 2 exhibits data from Slovakia and the Czech Republic, and a comparison with Estonia, the best-performing new EU member state. As well as highlighting the problem of corruption, the table also shows that generally the scale of economic corruption is not decreasing as transition continues. Only the indicator for bribes for getting things done is moving in the desired direction. 
Table 1

Transparency International CPI indexes 2011, selected countries

\begin{tabular}{|c|c|c|}
\hline Rank & Country & Index \\
\hline 1 & New Zealand & 9.5 \\
\hline 2 & Denmark & 9.4 \\
\hline 2 & Finland & 9.4 \\
\hline 4 & Sweden & 9.3 \\
\hline 29 & Estonia & 6.4 \\
\hline 35 & Slovenia & 5.9 \\
\hline 41 & Poland & 5.5 \\
\hline 57 & Czech Republic & 4.4 \\
\hline 66 & Slovakia & 4 \\
\hline 143 & Russia & 2.4 \\
\hline
\end{tabular}

Source: http://cpi.transparency.org/cpi2011/results/\#CountryResults

Table 2

Selected indicators of corruption in Slovakia and the Czech Republic - time trends

\begin{tabular}{|l|c|c|c|c|c|c|c|}
\hline \multicolumn{1}{|c|}{ Country } & Year & Observations & A & J & K & L & M \\
\hline Czech Republic & 2002 & 182 & 35.93 & 26.58 & 1.21 & 14.29 & $\ldots$ \\
\hline Czech Republic & 2005 & 208 & 29.73 & 36.82 & 1.98 & 25.49 & $\ldots$ \\
\hline Czech Republic & 2009 & 250 & 8.73 & 30.31 & 1.49 & 25.12 & 35.15 \\
\hline Slovakia & 2002 & 110 & 64.44 & 56.18 & 3.35 & 32.04 & \\
\hline Slovakia & 2005 & 143 & 35.87 & 38.20 & 2.02 & 13.64 & $\ldots$ \\
\hline Slovakia & 2009 & 275 & 11.63 & 23.06 & 2.31 & 33.11 & 20.67 \\
\hline Estonia & 2002 & 134 & 35.14 & 24.76 & 1.04 & 4.58 & $\ldots$ \\
\hline Estonia & 2005 & 172 & 18.31 & 7.97 & 0.18 & 3.68 & $\ldots$ \\
\hline Estonia & 2009 & 273 & 1.60 & 0.28 & 0.00 & 5.43 & 66.45 \\
\hline
\end{tabular}

Source: http://www.enterprisesurveys.org/

A - \% of firms expecting to give an informal payment to public officials (to get things done)

$\mathrm{J}-\%$ of firms expecting to give gifts to secure a government contract

$\mathrm{K}$ - Value of gift expected to secure government contract (\% of contract)

$\mathrm{L}-\%$ of firms identifying corruption as a major constraint

$\mathrm{M}-\%$ of firms believing the court system is fair, impartial and uncorrupted

\section{Democracy}

Expectations at the beginning of transition were optimistic, but today it is clear that the twenty-year CEE transition period has not seen a sustained development of democratic institutions and norms. 
Recent scandals in the Czech Republic (Veci Verejne) and in Slovakia (Gorila) comprehensively reported by both national and international media, indicate that the connections between economic lobbies and public officials are too close - exactly as Stiglitz $(1997,28)$ warned when discussing the limited capacity of politicians to serve the public interest (see also Šebo and Maceják 2008).

Other problems are the lack of a sense of individual responsibility, paternalism and fiscal illusion that remain important features of citizens' behavior. In Slovakia, $67 \%$ of respondents believed that their problems should be solved by the state (Bunčak et al. 2009). In the Czech Republic, the introduction of co-payments in health care significantly influenced regional elections in 2009, with social democrats using them as their main stick to beat the governing party. In both countries, many people act as though their social benefits are costless.

\section{Quality of the rule of law}

The possible success of outsourcing is also connected to the quality of the rule of law. If the state switches its role from provider to regulator, efficiency improvements are impossible where regulatory guidelines do not exist, and where the law is not respected. At present, it is clear that government officials do not routinely respect the law, and, perhaps the core problem, citizens do not require them to do so.

The administrative basis is also inadequate. Outsourcing occurs with no explanations, recommendations or guidelines for users. The countries have only recently started to switch to accrual accounting rules, but this is still insufficient because full cost accounting is confined to only a few public organizations, for example universities and hospitals.

To be effective, contracting also needs to be supported by new control and audit approaches that focus on legality and results. But the current systems of publicsector control/auditing employed in most if not all CEE countries predominantly adhere to the old-fashioned administrative procedural type of control. New laws on financial control were passed by national parliaments under pressure from Brussels, but in reality effective mechanisms to measure and create real efficiency, effectiveness and quality in public-sector institutions and processes are still missing (Pavel 2006).

\subsection{Contracting and outsourcing in Slovakia and Czechia and its results}

We have mapped contracting and outsourcing processes in the Czech Republic and in Slovakia for more than a dozen years. Our findings indicate that many local public services are contracted out and many internal services are outsourced to external suppliers. Tables 3 and 4 describe the situation in outsourcing, Table 5 deals with contracting local services. 
Table 3

Frequency of use of outsourcing of internal services - the Czech Republic, 2009

\begin{tabular}{|l|c|c|}
\hline \multicolumn{1}{|c|}{ Service } & Number of responses & Percentage of outsourced services \\
\hline Cleaning & 158 & $6.96 \%$ \\
\hline Catering & 25 & $31.20 \%$ \\
\hline Maintenance & 132 & $11.36 \%$ \\
\hline IT & 125 & $38.40 \%$ \\
\hline Transport & 111 & $18.02 \%$ \\
\hline Security & 92 & $26.09 \%$ \\
\hline
\end{tabular}

Note: own research

Table 4

Frequency of use of outsourcing of internal services - Slovakia, 2009

\begin{tabular}{|l|c|c|c|c|c|c|}
\hline & $\begin{array}{c}\text { Adminis- } \\
\text { tration }\end{array}$ & Education & $\begin{array}{c}\text { Health } \\
\text { care }\end{array}$ & Social & Culture & Total \\
\hline Catering & $90.00 \%$ & $17.74 \%$ & $21.43 \%$ & $20.00 \%$ & $62.50 \%$ & $42.33 \%$ \\
\hline Maintenance & $27.59 \%$ & $14.52 \%$ & $35.71 \%$ & $42.86 \%$ & $25.00 \%$ & $29.14 \%$ \\
\hline IT & $25.00 \%$ & $27.59 \%$ & $42.86 \%$ & $25.00 \%$ & $37.50 \%$ & $31.59 \%$ \\
\hline Transport & $3.70 \%$ & $15.15 \%$ & $7.14 \%$ & $0.00 \%$ & $0.00 \%$ & $5.20 \%$ \\
\hline Security & $64.00 \%$ & $42.50 \%$ & $45.45 \%$ & $0.00 \%$ & $42.86 \%$ & $38.96 \%$ \\
\hline
\end{tabular}

Note: own research, sample of 127 organizations

\section{Table 5}

Scale of external forms (contracting) of delivery of selected local public services in Slovak and Czech municipalities (\%)

\begin{tabular}{|l|c|c|c|c|c|}
\hline \multirow{2}{*}{ Service } & \multicolumn{3}{c|}{ Slovak Republic } & \multicolumn{2}{c|}{ Czech Republic } \\
\cline { 2 - 6 } & $\mathbf{2 0 0 0}$ & $\mathbf{2 0 0 5}$ & $\mathbf{2 0 0 5}$ TI & $\mathbf{2 0 0 0}$ & $\mathbf{2 0 0 4}$ TI \\
\hline Waste & 49 & 64 & 69 & 71 & 80 \\
\hline Cemeteries & 27 & 12 & 16 & 42 & 26 \\
\hline Public green areas & 16 & 18 & 33 & 45 & 24 \\
\hline Communications & 21 & 41 & 45 & 31 & 38 \\
\hline Public lighting & 30 & 35 & 40 & 23 & 60 \\
\hline
\end{tabular}

Note: original research based on data obtained from selected municipalities related to the local service delivery in 2001, 2006, 2007, and data gathered from results of research projects of Transparency International Slovakia and Czechia realized in 2006 and 2005. 
All data clearly indicate that outsourcing internal services and external delivery of local public services is a very frequent solution both in Slovakia and Czechia. Our findings also indicate that results from outsourcing and contracting are contradictory. As an illustration Table 6 shows one sample of data with unclear results; the same picture appears in all other samples.

Table 6

The efficiency of contracting out of local services in Slovakia (internal form $=100 \%$ )

\begin{tabular}{|l|c|c|c|}
\hline \multirow{2}{*}{\multicolumn{1}{c|}{ Service }} & $\mathbf{3}$ & \multicolumn{3}{c|}{ Year (\%) } \\
\cline { 2 - 4 } & $\mathbf{2 0 0 0}$ & $\mathbf{2 0 0 5}$ TI & $\mathbf{2 0 0 8}$ \\
\hline Waste & 94 & 125 & 184 \\
\hline Cemeteries & 64 & 67 & 146 \\
\hline Public parks & 82 & 150 & 151 \\
\hline Communications & 70 & 119 & 114 \\
\hline Public lighting & 100 & 128 & 156 \\
\hline
\end{tabular}

Note: Original research is based on the data obtained from selected municipalities related to local service delivery in 2001 and 2009, and data gathered from results of research projects of Transparency International Slovakia is realized in 2006.

\section{Quality of contract management in outsourcing and contracting in Slovakia}

Our data indicate that outsourcing and contracting are frequent, but deliver very mixed results. In such a situation, the attempt to assess factors determining the existing situation is obvious.

Table 7

The research sample

\begin{tabular}{|l|c|c|c|c|c|}
\hline \multirow{2}{*}{$\begin{array}{c}\text { Size of } \\
\text { municipality }\end{array}$} & \multirow{2}{*}{ Total } & \multicolumn{2}{|c|}{ Sample } & \multicolumn{2}{c|}{ \% of total } \\
\cline { 3 - 6 } & & $\mathbf{2 0 0 9}$ & $\mathbf{2 0 1 0}$ & $\mathbf{2 0 0 9}$ & $\mathbf{2 0 1 0}$ \\
\hline Below 999 & 1,926 & 49 & 34 & 2.54 & 1.70 \\
\hline $1,000-4,999$ & 833 & 56 & 58 & 6.72 & 7.00 \\
\hline $5,000-9,999$ & 60 & 9 & 17 & 15.00 & 28.33 \\
\hline $10,000-19,999$ & 32 & 8 & 12 & 25.00 & 37.50 \\
\hline $20,000-49,999$ & 29 & \multirow{2}{*}{9} & 14 & \multirow{2}{*}{22.50} & 48.28 \\
\cline { 1 - 2 } \cline { 6 - 6 } Over 50,000 & 11 & & 6 & & 54.55 \\
\hline Total & 2,891 & 131 & 141 & 4.53 & 4.88 \\
\hline
\end{tabular}

Note: Statistical Office Slovakia 
As indicated, in our paper, we focus on evaluating contract-management factors. The absence of systemic contract management is one of the core purposes for failures of contracting/outsourcing (Hodge 2000; Sclar 2000; Brudney et al. 2005; Kamerman and Kahn 1989). To collect data, we used the sample (Table 7).

For the purposes of this concrete research of the quality of contract management in outsourcing and contracting processes, we decided to use the following set of factors (determined by the Deplhi method):

$\mathrm{x}_{1}$ - level of competitiveness of the award,

$x_{2}$ - definition of the procured services/contract specifications,

$\mathrm{x}_{3}$ - selection criteria,

$\mathrm{x}_{4}$ - ex-ante evaluation: financial situation of bidders,

$\mathrm{x}_{5}$ - ex-ante evaluation: technical capacities of suppliers,

$\mathrm{x}_{6}$ - ex-ante evaluation: personnel capacities of bidders,

$\mathrm{x}_{7}$ - ex-ante evaluation: experience of bidders,

$\mathrm{x}_{8}$ - experience of the principal/government-body personnel,

$\mathrm{x}_{9}$ - frequency of contract monitoring,

$\mathrm{x}_{10}$ - sanctions,

$\mathrm{x}_{11}$ - duration of the contract,

$\mathrm{x}_{12}$ - method of payment to supplier/agent,

$\mathrm{x}_{13}$ - communication between principal and agent,

$\mathrm{x}_{14}$ - quality of cooperation between principal and agent,

$\mathrm{x}_{15}$ - level of trust between principal and agent.

All above-mentioned factors have qualitative character, thus we transformed them into quantitative data as follows (Table 8) and used them as described in Table 9. 
Table 8

Conversion to quantitative data

\begin{tabular}{|c|c|c|}
\hline Factor & Description & Points \\
\hline \multirow{5}{*}{$\begin{array}{l}\mathbf{x}_{1}-\text { level of competitiveness of } \\
\text { the award }\end{array}$} & Open tender & 100 \\
\hline & Restricted procedure & 70 \\
\hline & Negotiated procedure & 50 \\
\hline & Price quotation & 30 \\
\hline & Direct award & 0 \\
\hline \multirow{4}{*}{$\begin{array}{l}\mathbf{x}_{2} \text { - Is the service properly } \\
\text { defined in the contract? }\end{array}$} & Fully agree & 100 \\
\hline & Agree & 50 \\
\hline & Disagree & 0 \\
\hline & Fully disagree & 0 \\
\hline \multirow[t]{2}{*}{$\mathbf{x}_{\mathbf{3}}-$ selection criteria } & Best bid & 100 \\
\hline & Lowest price & 50 \\
\hline \multirow{4}{*}{$\begin{array}{l}\mathbf{x}_{4}-\text { ex-ante evaluation: Did the } \\
\text { principal evaluate the financial } \\
\text { situation of potential suppliers? }\end{array}$} & Fully agree & 100 \\
\hline & Agree & 50 \\
\hline & Disagree & 0 \\
\hline & Fully disagree & 0 \\
\hline \multirow{4}{*}{$\begin{array}{l}\mathbf{x}_{5}-\text { ex-ante evaluation: Did the } \\
\text { contractor evaluate the technical } \\
\text { capacities of potential suppliers? }\end{array}$} & Fully agree & 100 \\
\hline & Agree & 50 \\
\hline & Disagree & 0 \\
\hline & Fully disagree & 0 \\
\hline \multirow{4}{*}{$\begin{array}{l}\mathbf{x}_{6}-\text { ex-ante evaluation: Did the } \\
\text { contractor evaluate the human } \\
\text { resources of potential suppliers? }\end{array}$} & Fully agree & 100 \\
\hline & Agree & 50 \\
\hline & Disagree & 0 \\
\hline & Fully disagree & 0 \\
\hline \multirow{4}{*}{$\begin{array}{l}\mathbf{x}_{7}-\text { ex-ante evaluation: Did the } \\
\text { contractor evaluate previous } \\
\text { cooperation of potential suppliers } \\
\text { with the public sector? }\end{array}$} & Fully agree & 100 \\
\hline & Agree & 50 \\
\hline & Disagree & 0 \\
\hline & Fully disagree & 0 \\
\hline \multirow{4}{*}{$\begin{array}{l}\mathbf{x}_{\mathbf{8}}-\text { Has the involved principal's } \\
\text { staff sufficient expertise? }\end{array}$} & Fully agree & 100 \\
\hline & Agree & 50 \\
\hline & Disagree & 0 \\
\hline & Fully disagree & 0 \\
\hline \multirow[t]{3}{*}{$\mathbf{x}_{\mathbf{9}}-$ frequency of monitoring } & Regular & 100 \\
\hline & Irregular & 50 \\
\hline & No monitoring & 0 \\
\hline
\end{tabular}


Table 8

(continuation)

\begin{tabular}{|c|c|c|}
\hline Factor & Description & Points \\
\hline \multirow[t]{4}{*}{$\mathbf{x}_{\mathbf{1 0}}-$ Contract sanctions } & Cancellation of the contract & 100 \\
\hline & Financial sanctions & 70 \\
\hline & Right to request improvements & 30 \\
\hline & Other & 0 \\
\hline \multirow[t]{4}{*}{$\mathbf{x}_{11}$ - Length of contract } & One year or less & 100 \\
\hline & $1-2$ years & 70 \\
\hline & $2-5$ years & 30 \\
\hline & Unlimited & 0 \\
\hline \multirow{3}{*}{$\begin{array}{l}\mathbf{x}_{12}-\text { method of payment to } \\
\text { supplier }\end{array}$} & Performance payment & 100 \\
\hline & Mixed performance and lump-sum payment & 50 \\
\hline & Lump-sum payment & 0 \\
\hline \multirow[t]{4}{*}{$\mathbf{x}_{\mathbf{1 3}}-$ communication with supplier } & Frequent & 100 \\
\hline & Regular & 70 \\
\hline & Irregular & 30 \\
\hline & Limited or none at all & 0 \\
\hline \multirow{4}{*}{$\begin{array}{l}\mathbf{x}_{\mathbf{1 4}}-\text { The quality of cooperation } \\
\text { between principal and agent is } \\
\text { high. }\end{array}$} & Fully agree & 100 \\
\hline & Agree & 50 \\
\hline & Disagree & 0 \\
\hline & Fully disagree & 0 \\
\hline \multirow{4}{*}{$\begin{array}{l}\mathbf{x}_{15}-\text { The level of trust between } \\
\text { principal and agent is high. }\end{array}$} & Fully agree & 100 \\
\hline & Agree & 50 \\
\hline & Disagree & 0 \\
\hline & Fully disagree & 0 \\
\hline
\end{tabular}

Note: own research

Table 9

The use of indicators in our research

\begin{tabular}{|l|c|c|}
\hline \multirow{2}{*}{\multicolumn{1}{c|}{ Areas }} & \multicolumn{2}{c|}{ Indicators used } \\
\cline { 2 - 3 } & $\begin{array}{c}\text { Contracting local } \\
\text { services }\end{array}$ & $\begin{array}{c}\text { Outsourcing internal } \\
\text { services }\end{array}$ \\
\hline Procurement process & $\mathrm{x}_{1}$ & $\mathrm{x}_{1} ; \mathrm{x}_{2}$ \\
\hline Selection criteria & $\mathrm{x}_{3}$ & $\mathrm{x}_{3} ; \mathrm{x}_{4} ; \mathrm{x}_{5} ; \mathrm{x}_{6} ; \mathrm{x}_{7} ; \mathrm{x}_{8}$ \\
\hline Contract conditions & $\mathrm{x}_{9} ; \mathrm{x}_{10} ; \mathrm{x}_{11}$ & $\mathrm{x}_{9} ; \mathrm{x}_{10} ; \mathrm{x}_{11}$ \\
\hline Relations principal $\mathrm{x}$ agent & $\mathrm{x}_{12}$ & $\mathrm{x}_{12} ; \mathrm{x}_{13} ; \mathrm{x}_{14} ; \mathrm{x}_{15}$ \\
\hline
\end{tabular}

Note: own research 
The findings are provided by Tables 10 (contracting) and 11 to 14 (outsourcing). The average quality is approximately 60 percent, better values have light shadow background.

Table 10

Quality of contract management for contracting out local services

\begin{tabular}{|l|c|c|c|c|c|c|}
\hline \multicolumn{1}{|c|}{ Service } & $\begin{array}{c}\text { Competi- } \\
\text { tiveness }\end{array}$ & $\begin{array}{c}\text { Ex-ante } \\
\text { evalua- } \\
\text { tion }\end{array}$ & $\begin{array}{c}\text { Monitor- } \\
\text { ing }\end{array}$ & $\begin{array}{c}\text { Sanc- } \\
\text { tions }\end{array}$ & $\begin{array}{c}\text { Contract } \\
\text { length }\end{array}$ & $\begin{array}{c}\text { Payment } \\
\text { condi- } \\
\text { tions }\end{array}$ \\
\hline Waste & 42.84 & 67.12 & 70.32 & 42.08 & 38.63 & 65.65 \\
\hline Public lighting & 47.11 & 72.73 & 65.26 & 45.20 & 44.77 & 63.72 \\
\hline $\begin{array}{l}\text { Local } \\
\text { communications }\end{array}$ & 50.12 & 64.40 & 64.13 & 43.50 & 52.96 & 74.15 \\
\hline Public green & 58.89 & 66.39 & 54.72 & 46.81 & 67.06 & 75.90 \\
\hline Cemeteries & 29.43 & 68.27 & 64.29 & 45.18 & 37.69 & 45.79 \\
\hline Average & $\mathbf{4 5 . 6 8}$ & $\mathbf{6 7 . 7 8}$ & $\mathbf{6 3 . 7 4}$ & $\mathbf{4 4 . 5 5}$ & $\mathbf{4 8 . 2 2}$ & $\mathbf{6 5 . 0 4}$ \\
\hline
\end{tabular}

Note: own research

Table 11

Quality of contract management for outsourcing internal services: procurement process

\begin{tabular}{|l|c|c|}
\hline & Competitiveness & Defining the service \\
\hline Cleaning & 45.28 & 57.50 \\
\hline Catering & 32.91 & 65.22 \\
\hline Maintenance & 52.11 & 69.86 \\
\hline IT management & 38.52 & 61.28 \\
\hline Transport & 28.81 & 69.14 \\
\hline Security & 37.14 & 60.94 \\
\hline Average & $\mathbf{3 9 . 1 3}$ & $\mathbf{6 3 . 9 9}$ \\
\hline
\end{tabular}

Note: own research 


\section{Table 12}

Quality of contract management for outsourcing internal services: selection criteria

\begin{tabular}{|l|c|c|c|c|c|c|}
\hline & $\begin{array}{c}\text { Selection } \\
\text { criteria }\end{array}$ & $\begin{array}{c}\text { Financial } \\
\text { capaci- } \\
\text { ties: sup- } \\
\text { plier }\end{array}$ & $\begin{array}{c}\text { Technical } \\
\text { capaci- } \\
\text { ties: sup- } \\
\text { plier }\end{array}$ & $\begin{array}{c}\text { Human } \\
\text { capaci- } \\
\text { ties: sup- } \\
\text { plier }\end{array}$ & $\begin{array}{c}\text { Experi- } \\
\text { ence of } \\
\text { supplier }\end{array}$ & $\begin{array}{c}\text { Principal } \\
\text { capacity }\end{array}$ \\
\hline Cleaning & 58.34 & 33.34 & 51.95 & 54.17 & 45.28 & 48.06 \\
\hline Catering & 73.90 & 61.69 & 67.28 & 63.08 & 62.79 & 69.69 \\
\hline Maintenance & 73.83 & 67.98 & 77.86 & 71.60 & 67.12 & 74.16 \\
\hline $\begin{array}{l}\text { IT } \\
\text { management }\end{array}$ & 71.39 & 59.26 & 73.81 & 69.49 & 67.38 & 64.53 \\
\hline Transport & 69.58 & 63.56 & 69.63 & 62.78 & 48.58 & 58.97 \\
\hline Security & 57.25 & 51.10 & 63.81 & 56.71 & 55.84 & 66.50 \\
\hline Average & $\mathbf{6 7 . 3 8}$ & $\mathbf{5 6 . 1 5}$ & $\mathbf{6 7 . 3 9}$ & $\mathbf{6 2 . 9 7}$ & $\mathbf{5 7 . 8 3}$ & $\mathbf{6 3 . 6 5}$ \\
\hline
\end{tabular}

Note: own research

\section{Table 13}

Quality of contract management for outsourcing internal services: contract conditions

\begin{tabular}{|l|c|c|c|}
\hline & Monitoring & Sanctions & Contract length \\
\hline Cleaning & 56.95 & 57.22 & 43.89 \\
\hline Catering & 55.25 & 67.46 & 30.54 \\
\hline Maintenance & 63.43 & 50.32 & 56.08 \\
\hline IT management & 58.97 & 51.39 & 44.74 \\
\hline Transport & 71.25 & 48.25 & 60.56 \\
\hline Security & 59.52 & 45.76 & 33.05 \\
\hline Average & $\mathbf{6 0 . 9}$ & $\mathbf{5 3 . 4}$ & $\mathbf{4 4 . 8 1}$ \\
\hline
\end{tabular}

Note: own research 
Table 14

Quality of contract management for outsourcing internal services: principal $\mathrm{x}$ agent relations

\begin{tabular}{|l|c|c|c|c|}
\hline & Payment & Communication & Cooperation & Trust \\
\hline Cleaning & 31.39 & 60.84 & 59.17 & 46.39 \\
\hline Catering & 56.32 & 60.68 & 78.42 & 73.71 \\
\hline Maintenance & 74.81 & 59.76 & 83.65 & 75.54 \\
\hline IT management & 58.02 & 62.25 & 76.33 & 70.61 \\
\hline Transport & 75.00 & 49.22 & 74.61 & 64.81 \\
\hline Security & 47.05 & 48.99 & 72.15 & 72.23 \\
\hline Average & $\mathbf{5 7 . 1}$ & $\mathbf{5 6 . 9 5}$ & $\mathbf{7 4 . 0 5}$ & $\mathbf{6 7 . 2 2}$ \\
\hline
\end{tabular}

Note: own research

The data obtained by our direct research indicate that the quality of contract management is limited. Better results are normally received for soft indicators, where evaluation is based on the subjective opinion/response from the staff involved. A critical level is achieved for main hard indicators, especially the level of competitiveness.

\subsection{Testing the relationships between factors and results of contracting/outsourcing}

In this part, we calculate the Spearman's correlation to test the correlation between a dependent variable (efficiency of contracting/outsourcing - data not included in this paper) and independent variables - respective quality of contract-management factors. With $\alpha=0.1$ we used the statistical systems R and IMB to test the following:

$\mathrm{H}_{0}: \rho_{\mathrm{s}}=0$ (no statistically significant correlation)

$\mathrm{H}_{1}: \rho_{\mathrm{s}} \neq 0$ (statistically significant correlation exists)

The results are provided by Tables 15 and 16 . 
Table 15

Correlations for contracting local services

\begin{tabular}{|l|c|c|c|c|}
\hline \multicolumn{1}{|c|}{ Service } & Factor & p value & $\begin{array}{c}\text { Spearman's correlation } \\
\text { coefficient }\end{array}$ & Correlation \\
\hline \multirow{3}{*}{ Waste } & $\mathrm{x}_{1}$ & 0.000 & 0.333 & Positive \\
\cline { 2 - 5 } & $\mathrm{x}_{9}$ & 0.031 & 0.209 & Positive \\
\cline { 2 - 5 } & $\mathrm{x}_{11}$ & 0.005 & 0.271 & Positive \\
\hline Public lighting & $\mathrm{x}_{1}$ & 0.000 & 0.579 & Positive \\
\hline Local communications & $\mathrm{x}_{1}$ & 0.000 & 0.666 & Positive \\
\hline \multirow{2}{*}{ Public green } & $\mathrm{x}_{1}$ & 0.000 & 0.804 & Positive \\
\cline { 2 - 5 } & $\mathrm{x}_{12}$ & 0.083 & 0.361 & Positive \\
\hline Cemeteries & $\mathrm{x}_{1}$ & 0.001 & 0.731 & Positive \\
\hline
\end{tabular}

Note: own research

Table 16

Correlations for outsourcing internal services

\begin{tabular}{|l|c|c|c|c|}
\hline \multicolumn{1}{|c|}{ Service } & Factor & p value & Spearman coefficient & Correlation \\
\hline \multirow{4}{*}{ Cleaning } & $\mathrm{x}_{3}$ & 0.062 & -0.579 & Negative \\
\cline { 2 - 6 } & $\mathrm{x}_{14}$ & 0.027 & 0.659 & Positive \\
\hline \multirow{4}{*}{ Catering } & $\mathrm{x}_{1}$ & 0.003 & 0.329 & Positive \\
\cline { 2 - 6 } & $\mathrm{x}_{4}$ & 0.034 & 0.242 & Positive \\
\cline { 2 - 6 } & $\mathrm{x}_{5}$ & 0.061 & 0.215 & Positive \\
\cline { 2 - 6 } & $\mathrm{x}_{6}$ & 0.008 & 0.301 & Positive \\
\hline \multirow{3}{*}{ IT } & $\mathrm{x}_{1}$ & 0.004 & 0.444 & Positive \\
\hline \multirow{3}{*}{ Transport } & $\mathrm{x}_{2}$ & 0.053 & -0.221 & Negative \\
\hline \multirow{5}{*}{ Security } & $\mathrm{x}_{1}$ & 0.064 & 0.384 & Positive \\
\cline { 2 - 6 } & $\mathrm{x}_{13}$ & 0.018 & 0.478 & Positive \\
\cline { 2 - 6 } & $\mathrm{x}_{1}$ & 0.002 & 0.481 & Positive \\
\cline { 2 - 6 } & $\mathrm{x}_{2}$ & 0.071 & 0.288 & Positive \\
\cline { 2 - 5 } & $\mathrm{x}_{3}$ & 0.005 & -0.431 & Negative \\
\cline { 2 - 5 } & $\mathrm{x}_{4}$ & 0.013 & 0.391 & Positive \\
\cline { 2 - 5 } & $\mathrm{x}_{8}$ & 0.028 & 0.347 & Positive \\
\cline { 2 - 5 } & $\mathrm{x}_{13}$ & 0.035 & 0.334 & Positive \\
\hline
\end{tabular}

Note: own research

The results indicate that few statistically significant factors can be identified for contracting. Similarly to other researches, we found that among the most im- 
portant factors are the level of competitiveness of the award, the monitoring of the services and the form of payment. The results for contract duration are not so clear, because for different services, different contract duration is most effective (in our research, we expect that shorter contracts have a positive impact on contracting performance).

Concerning outsourcing our research indicates that besides the level of competitiveness, factors like selection criteria, quality of ex-ante evaluation, cooperation and experience also play an important role.

\section{Conclusions}

Contracting and outsourcing are relatively frequent solutions in the public sector of developed, but also developing countries. In this paper, we summarize findings from our research. According to our results, contracting and outsourcing may, but need not, improve the efficiency compared to internal delivery.

Both general and region-specific factors determine such a situation. In this paper, we used the Slovak sample to try to measure the impact of qualitative factors (selected by the Delphi method) determining the success in contracting and outsourcing. The results indicate that there are several important determinants for success; probably the most important one is the level of competitiveness of award. In light of this finding, it is painful to see that the majority of contracts is signed on the basis of non-competitive selection of suppliers, and this trend does not significantly improve, as our data for a period of more than ten years indicate. To change this situation, accountability needs to become a real value in our public-administration systems, and the control has to focus not only on processes but also on results.

\section{References}

Arrow, K. J. 1985. “The Economics of Agency." In J. W. Pratt and R. J. Zeckhauser (eds). Principals and Agents: The Structure of Business. Boston: Harvard Business School Press, 37-51.

Bailey, S. J. 1999. Public Sector Economics. London: Macmillan.

Balážová, E. 2006. Benchmarking služieb miestnej samosprávy na Slovensku. Bratislava: TIS.

Beblavý, M. and E. Sičáková-Beblavá. 2006 Inštitucionálne dilemy pri zabezpečovaní verejných služieb. Prešov: TIS.

Bel, G. and A. Costas. 2006. "Do Public Sector Reforms Get Rusty? An Empirical Analysis on Privatization of Solid Waste Collection." The Journal of Policy Reform 9 (1), 1-24. 
Brown, T. L. and M. Potoski. 2003 "Contract-Management Capacity in Municipal and County Governments." Public Administration Review 63, 153-164.

Brudney, J. L., S. Fernandez, J. E. Ryu and D. S. Wright. 2005. "Exploring and Explaining Contracting Out: Patterns Among the American States." Journal of Public Administration Research and Theory 15, 393-419.

Bunčák, J., R. Džambazovič, A. Hrabovská and J. Sopóci. 2008. Názory občanov na budúcnost' Slovenska. Bratislava: EÚ SAV.

Cooper, P. J. 2003. Governing by Contract. Washington D.C.: CQ Press.

DeHoog, R. H. 1990. "Competition, Negotiation, or Cooperation: Three Models for Service Contracting." Administration and Society 22, 317-340.

Engelbeck, R. M. 2004. Using Metrics to Manage Contractor Performance. Graduate School of Business \& Public Policy at the Naval Postgraduate School. Available at http://www.acquisitionresearch.org/_files/FY2004/NPS-CM-04-011. pdf (last accessed 15 April 2012).

Epstein, P. D. 1984. Using Performance Measurement in Local Government. New York: Van Nostrand Reinhold Company Inc.

Ferris, J. and P. Graddy. 1996. Institutional Economics and Government Contracting: Lessons for the New Public Management. Paper prepared for the conference on The New Public Management in International Perspective, Institute of Public Finance and Fiscal Law, 11-13 July in St Gallen, Switzerland. Available at http://www.inpuma.net/research/conference/Papers/fergrad.doc (last accessed 15 April 2012).

Greene, J. D. 2002. Cities and Privatization: Prospects for the New Century. Upper Saddle River, New Jersey: Prentice Hall.

Hefetz, A. and M. Warner. 2004. "Privatization and its Reverse: Explaining the Dynamics of the Government Contracting Process." Journal of Public Administration Research and Theory 14, 171-190.

Hirsch, W. Z. 1991. Privatizing Government Services: An Economic Analysis of Contracting by Local Governments. Los Angeles: Institute of Industrial Relations, Publications Centre, University of California.

Hodge, G. A. 2000. Privatization: An International Review of Performance. Boulder, CO: Westview Press.

Kamerman, S. B. and A. J. Kahn. 1989. Privatization and the Welfare State. Princeton: Princeton University Press.

Kettl, D. F. 1993. Sharing Power: Public Governance and Private Markets. Washington D.C.: The Brookings Institution.

Lane, J. E. 2000. New Public Management. London: Routledge Taylor Francis Group. 
Lowery, D. 1998. "Consumer Sovereignty and Quasi-Market Failure." Journal of Public Administration Research and Theory 8 (2), 137-172.

Majlingová, L. and V. Šagát. 2006. "Zabezpečovanie služieb miestnou samosprávou." Acta Aerarii Publici 3 (2), 34-41.

Marlin, J. T. 1984. Contracting Municipal Services: A Guide for Purchase from the Private Sector. New York: Wiley.

Macneil, I. R. 1978. "Contracts: Adjustments of Long-Term Economic Relations under Classical, Neoclassical and Relational Contract Law." Northwestern University Law Review 72, 855-905.

Meričková, B. 2010. "Faktory efektívnosti efektívnosti kontrahovania služieb vo verejnom sektore." In Květa Kubátová (ed.). Teoretické a praktické aspekty veřejných financií. Praha: Vysoká škola ekonomická Praha, Oeconomica.

Meričková, B., J. Nemec and F. Ochrana. 2008. "Introducing Benchmarking in the Czech Republic and Slovakia: Processes, Problems and Lessons." Public Management Review 10 (5), 673-684.

Meričková, B., J. Nemec, E. Sičáková-Beblavá and M. Beblavý. 2010 Kontrahovanie služieb vo verejnom sektore. Bratislava: Transparency International Slovensko.

Meričková, B., J. Nemec and L. Vítek. 2005. "Contracting-out at Local Government Level: Theory and Selected Evidence from Czech and Slovak Republics." Public Management Review 7 (4), 638-647.

More, T. M. 1984. “The New Economics of Organization." American Journal of Political Science 4 (28), 739-777.

Ochrana, F. 2007. Veřejné služby: jejich poskytování, zadávaní a hodnocení. Praha: Ekopress.

Øvretveit, J. 1995. Purchasing for Health. London: Oxford University Press.

Pavel, J. 2007. Ekonomické aspekty veřejných zakázek. Praha: Vysoká škola ekonomická v Praze.

Pavel, J. 2006. Efektivnost a transparentnost obecních obchodních spolecností. Transparency International Czech Republic. Available at http://www.transparency. cz/pdf/vz_obecni_firmy_pavel.pdf (last accessed 15 April 2012).

Pavel, J. and E. Beblavá. 2008. “Transparentnost trhu verejného obstarávania." Ekonomický časopis 56 (2), 168-181.

Pollitt, Ch. and G. Bouckaert. 2000. Public Management Reform: A Comparative Analysis. London: Oxford University Press.

Prager, J. 1994. "Contracting Out Government Services: Lessons from the Private Sector.” Public Administration Review 54 (2), 176-184. 
Pratt, J. W. and R. J. Zeckhauser. 1986. "Principals and Agents: The Structure of Business." Journal of Economic Literature 24 (4), 1788-1789.

Rehfuss, J. A. 1989. Contracting Out in Government. San Francisco: Jossey-Bass.

Romzek, B. S. and J. M. Johnston. 2002. "Effective Contract Implementation and Management: A Preliminary Model." Journal of Public Administration Research and Theory 12, 423-453.

Savas, E. S. 1987. Privatisation: The Key to Government. New York: Chatman House.

Sclar, E. D. 2000. You Don't Always Get What You Pay For: The Economics of Privatization. Ithaca: Cornell University Press.

Šebo, J. and Š. Maceják. 2008. Záujmové organizácie a lobing. Banská Bystrica: Ekonomická fakulta UMB.

Seidenstat, P. 1999. Contracting Out Government Services. Westport: Praeger.

Shetterly, D. R. 1998. "The Influence of Contract Designs on Contractor Performance." Public Performance \& Management Review 24 (1), 53-68.

Stiglitz, J. E. 1997. Economics of the Public Sector. New York: W. W. Norton \& Company. 